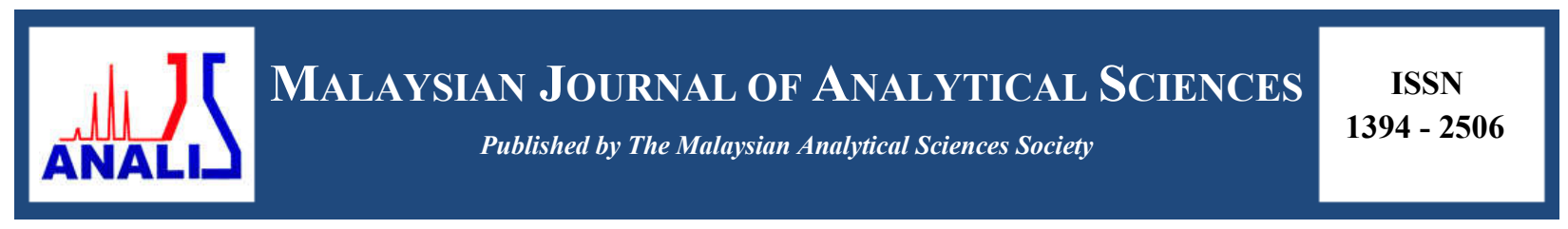

\title{
TWO ISOLATED CRYSTALLINE SOLIDS FROM THE STEM OF Entada spiralis Ridl. (AKAR SINTOK)
}

\author{
(Pemencilan Dua Jenis Pepejal Kristal dari Batang Pokok Entada spiralis (Akar Sintok)) \\ Aiza Harun ${ }^{1 *}$, Siti Zaiton Mat So’ad², Norazian Mohd Hassan² \\ ${ }^{1}$ Faculty of Applied Sciences, \\ Universiti Teknologi MARA Pahang, 26400 Bandar Tun Razak Jengka, Pahang, Malaysia \\ ${ }^{2}$ Kulliyah of Pharmacy, \\ International Islamic University Malaysia, Bandar Indera Mahkota, Kuantan Pahang, Malaysia
}

*Corresponding author: aizaharun@pahang.uitm.edu.my

Received: 30 November 2015; Accepted: 1 February 2016

\begin{abstract}
Entada spiralis Ridl. (Leguminosae) is a woody climber which locally known as 'akar sintok'. The isolation and structure determination of two crystalline solids from active methanol fraction of E. spiralis stem bark had been examined. The structure identification of both solids was based on spectroscopic data $\left({ }^{1} \mathrm{H}\right.$ and ${ }^{13} \mathrm{C}$ NMR, HMQC, HMBC, DEPT135 and MS) along with comparison with literature data. The results revealed that these two crystalline solid sugars isolated from the most active fraction were known as penta-2-acetoxy- $\beta$-D-digitoxopyranosyl-( $1 \rightarrow 2)$-fructofuranosyl- $(6 \rightarrow 4)-\beta$-D-glucopyranosyl- $(1 \rightarrow 4)$ -

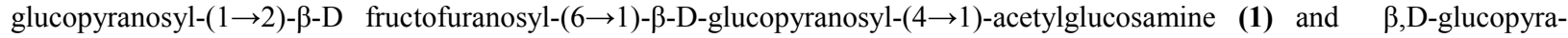
$\operatorname{nosyl}(1 \rightarrow 2)-\beta$,D-glucopyranosyl)-( $1 \rightarrow 3)-\beta$,D-xylopyranosyl $(1 \rightarrow 4)-\alpha$, L-rhamnopyranosyl)-( $1 \rightarrow 3)-\beta$,D- glucopyranosyl $(1 \rightarrow 3)$ $\beta, D$-glucopyranoside (2) Thus, this finding can be utilized as a scientific baseline information for further skin disease studies, since both constituents were isolated from moderate antidermatophytic active fraction.
\end{abstract}

Keywords: Entada spiralis, crystalline saponin, glycosides, isolation

\section{Abstrak}

Pemencilan dan penentuan struktur dua komponen bersifat kristal dari batang pokok E. spiralis yang juga dikenali sebagai akar sintok telah dijalankan. Eksperimen penentuan struktur berdasarkan data - data spektroskopi menggunakan ${ }^{1} \mathrm{H},{ }^{13} \mathrm{C}$ NMR, HMQC, HMBC, DEPT135 dan spektrometer jisim dan juga perbandingan dengan kajian terdahulu. Hasil analisa spektroskopi yang terperinci menunjukkan kedua - dua kristal tersebut dikenali sebagai penta-2-asetoksi- $\beta$-D-digitoxopiranosil-( $1 \rightarrow 2)$ fruktofuranosil- $(6 \rightarrow 4)-\beta$-D-glukopiranosil-( $1 \rightarrow 4)$-glukopiranosil-( $1 \rightarrow 2)-\beta$-D fruktofuranosil-( $6 \rightarrow 1)-\beta$-D-glukopiranosil-( $4 \rightarrow 1)-$ acetilglukosamina (1) and $\beta$, D-glukopiranosil $(1 \rightarrow 2)-\beta, D$-glukpiranosil)-( $1 \rightarrow 3)-\beta, D$-xilopiranosil( $(1 \rightarrow 4)-\alpha, L-$ rhamnopiranosil)$(1 \rightarrow 3)$ - $\beta$,D-glukopiranosil $(1 \rightarrow 3)-\beta, D$-glukopiranosid $(2)$. Penemuan ini boleh dijadikan maklumat asas untuk kajian penyakit kulit kerana kedua-dua komponen ini dipencilkan dari fraksi metanol yang bersifat antiderma.

Kata kunci: Entada spiralis, kristal saponin, glikosid, pemencilan

\section{Introduction}

Medicinal herbs have been consumed traditionally by people throughout the world to cure various diseases long enough before the emerging of modern medicine. Due to their higher content of such valuable chemical compounds, they could be used to prevent microbial invasion. Secondary metabolites produced by plants contain a tremendous source of bioactive compounds such as flavonoid, alkaloid, tannin, saponin and terpenoid. Knowing their 
importance, scientific investigation has increased rapidly to overcome the development of resistant pattern of certain microorganisms such as skin disease caused microbes [1].

The structure identification of bioactive constituents from the various types of species of Leguminoceae family had been reported [2-6]. The stem of E. spiralis is believed to exhibit antimicrobial properties since it is capable to treat hair problem, itching and body cleansing. Previous phytochemical investigation of other Entada species encountered oleanolic acid, echinocystic acid, entagenic acid and acacic acid glycosides Okada et al. [7, 8]. E. rheedii Spreng was found to possess saponins [7-10], thiomides [11] and phenylacetic derivatives [12-13]. Investigation also revealed entagenic acid isolated from seed kernels of E.rheedii which exhibited moderate cytotoxic potency and antioxidative properties [14]. Phenolic and flavonoid were isolated from the root of E. Africa [15], octadecanoic acid from the stem bark of E. abyssinica [16] and Entadoiside from kernel nut of E. phaseoloides [17].

In this present study, we embark upon isolation and structure identification of two novel crystalline solids from active fractions of E.spiralis stem bark.

\section{General Experimental Procedures}

\section{Materials and Methods}

The general experimental procedures were adapted from Aiza et al. [18]. The ${ }^{1} \mathrm{H}$ Nuclear Magnetic Resonance (NMR) and ${ }^{13} \mathrm{C}$ NMR spectra were recorded in $\mathrm{CDCl}_{3}$, Fourier Transform NMR (FT-NMR) analysis was done using a Cryoprobe on a Bruker Avance $111600 \mathrm{MHz}$ spectrometer. Tetramethylsilane (TMS) was used as an internal standard in NMR spectrometer analysis. Electronspray ionization mass spectrometer (ESIMS) was performed using a Bruker micrOTOF-Q 86 mass spectrometer operating in positive-ion mode. Vacuum liquid chromatography (VLC) was conducted using silica gel 60 with a $230-400$ mesh particle size (Merck). Thin layer chromatography (TLC) was performed on Kiesegel 60 F254 (Merck) aluminium support plates developed using chloroform: methanol system. TLC plates were visualized at $\mathrm{UV}_{366}$ and $\mathrm{UV}_{254}$.

\section{Fractionation and Isolation}

The extraction and fractionation procedures were conducted as previously reported with few modifications [19, 20]. The extraction process involved consecutive soaking with petroleum ether, chloroform and methanol, fractionation process was conducted using vacuum liquid chromatography with the use of several binary solvents to obtain fractions.

\section{Antidermatophytic Evaluation}

The antidermatophytic activity of fractions was determined as previously reported by Aiza et al [21]. Generally, all extracts were used against three types of skin diseases dermatophytes namely as Trychophyton tonsurans, Trychophyton mentagrophytes and Microsporum gypseum through disc diffusion method susceptibility testing. The effectiveness of the fractions was evaluated by means of inhibition zone (IZ) measurement around the disk.

\section{Results and Discussion}

Compound (1) was obtained as white crystalline solid after subjecting methanol extract to vacuum liquid chromatography with an elution system of $\mathrm{CHCl}_{3}-\mathrm{MeOH}(6: 4 \mathrm{v} / \mathrm{v})$ to obtain fraction 1 which was previously found to possess moderate antidermatophytic activity [20]. The melting point of white crystalline solid was $187^{\circ} \mathrm{C}$ and two ultra violet (UV) absorption peaks appeared at $228 \mathrm{~nm}$ and $280 \mathrm{~nm}$ when analyzed with UV VIS-1800 Series (Shimadzu, Japan). The results indicated the absorption of light in the region of $200-300 \mathrm{~nm}$, corresponded to the presence of atom with non-bonding orbital such as oxygen and nitrogen. Two peaks observed in the UV spectra were due to the presence of the chromophores, molecules that absorb light with bathochromic effect.

The Electron Spray Ionization Mass Spectrum (ESIMS) of compound (1) showed an $[\mathrm{M}+\mathrm{H}]^{+}$ion peak at $\mathrm{m} / z 1905$ in accordance with the molecular formula of $\mathrm{C}_{78} \mathrm{H}_{123} \mathrm{NO}_{52}$. The fragment ion peaks were observed on the ESIMS at $m / z \quad 1049 \quad[\mathrm{M}+\mathrm{H}-171-172-171-171-171], \quad 365[\mathrm{M}+\mathrm{H}-171-172-171-171-171-342-342]$ corresponding, to the consecutive loss of five pentosyls, two hexoxyls (Glc and Fru) and again two hexoxyls (Glc and Fru) respectively. Table 1 and Figure 1 showed the fragmentation of sugar moieties in the whole structure. 
Table 1. Fragmentation of ions in compound (1) by ESIMS

\begin{tabular}{cl}
\hline Mass & Fragmentation of ions \\
\hline 1734 & $[\mathrm{M}+\mathrm{H}]-171]^{+}$ \\
1562 & $[\mathrm{M}+\mathrm{H}]-171-172]^{+}$ \\
1391 & $[\mathrm{M}+\mathrm{H}]-171-172-171]^{+}$ \\
1220 & $[\mathrm{M}+\mathrm{H}]-171-172-171-171]^{+}$ \\
1049 & $[\mathrm{M}+\mathrm{H}]-171-172-171-171-171]^{+}$ \\
707 & $[\mathrm{M}+\mathrm{H}]-171-172-171-171-171-342]^{+}$ \\
365 & $[\mathrm{M}+\mathrm{H}]-171-172-171-171-171-342-342]^{+}$ \\
\hline
\end{tabular}

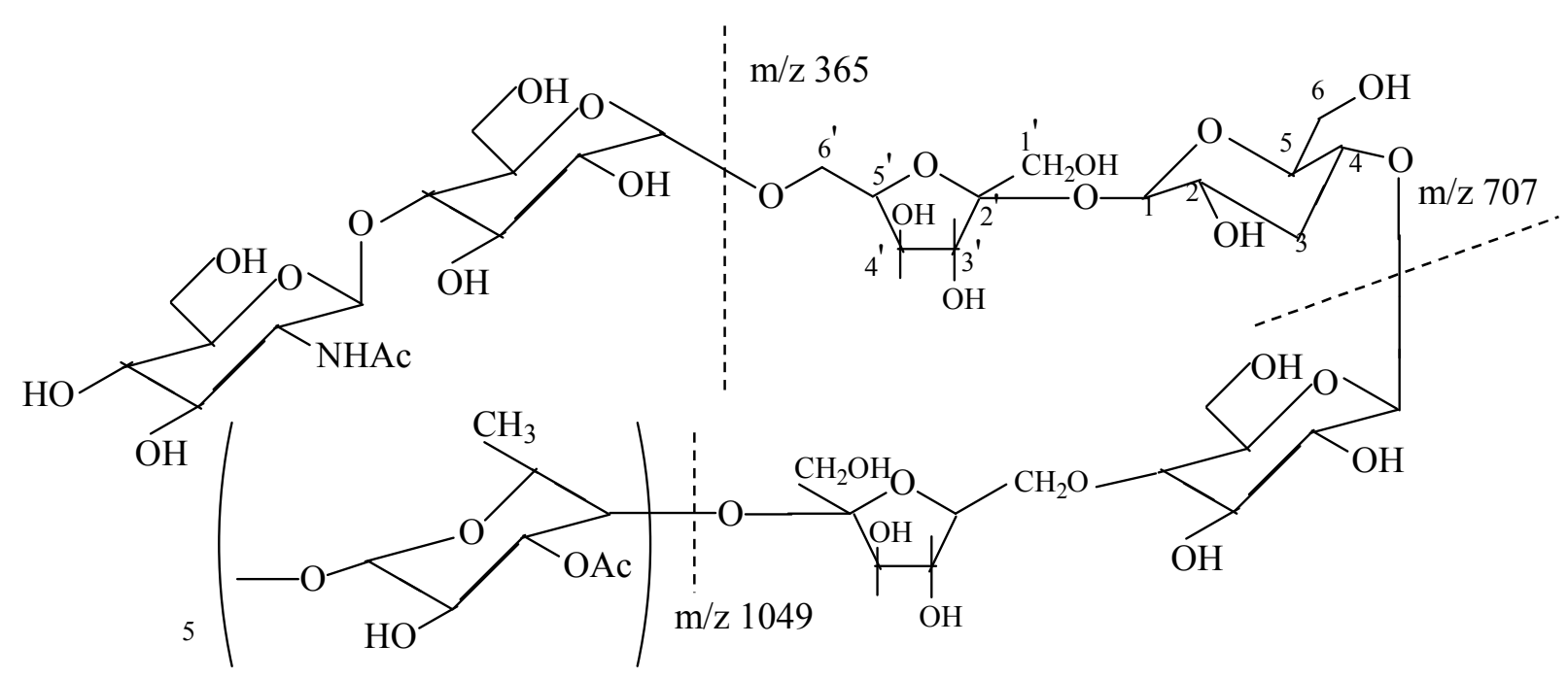

Figure 1. The mass fragmentation of compound (1) from E. spiralis stem bark

The ${ }^{1} \mathrm{H}$ NMR spectrum of compound (1) displayed three sugar anomeric protons at chemical shifts, ppm $\delta$ 4.41, 5.18 and 4.80, which indicated the presence of sugar moieties GlcNAc, Glc, acetyl digitoxose, respectively. These values were quite close to those reported in literature. The $\delta_{\mathrm{H}}$ for GlcNAc was reported [22] as $4.40 \mathrm{ppm}, \delta_{\mathrm{H}} 5.44$ and $\delta_{\mathrm{H}} 5.0$ for acetyl digitoxose [23]. The proton NMR spectrum furnished nine hydroxyl protons at chemical shifts $\delta_{\mathrm{H}} 3.14,3.20,3.47,3.49,3.55,3.58,3.68,3.78$ and 3.90 , giving direct coupling with nine carbon atoms at $\delta 70.30$, $72.09,73.27,60.95,62.59,83.01,73.33,74.74$ and $77.47 \mathrm{ppm}$, respectively based on HMQC spectrum. The correlation between $\delta_{\mathrm{H}} 5.18$ and chemical shifts of carbon at $\delta_{\mathrm{C}} 92.21$ corresponded to the direct correlation of anomeric proton and anomeric carbon of Glc.

According to ${ }^{13} \mathrm{C}$ NMR spectrum, the chemical shifts at $\delta_{\mathrm{C}} 104.49$ and $\delta_{\mathrm{C}} 92.21$ suggested the presence of anomeric carbon for fructose (Fru) and glucose (Glc) respectively, and were quite close to those reported for Fru $\left(\delta_{\mathrm{C}} 104.0\right)$ and Glc $\left(\delta_{\mathrm{C}} 93.9\right)[10,21]$. The high intensity of overlapped peaks indicated more than one sugar present and this was same for absorption peaks of carbon hydroxyl. Thus, it may explain why compound (1) showed high molecular weight as displayed in the mass spectrum. 
Long range correlations observed in the HMBC spectrum between signals at $\delta_{\mathrm{H}} 5.18$ (Glc-I) and $\delta_{\mathrm{C}} 104.49$ (C2'Fru) showed three bond correlations between Glc and Fru. The four bond correlation was observed between anomeric proton of GlcNAc $\delta 4.4$ and $\delta_{\mathrm{C}} 73.27$ (C3-Glc-II) suggested the location GlcNAc in AC1 structure. The anomeric proton of Glc-II $\left(\delta_{\mathrm{H}} 5.18\right)$ was linked with Fru by four bond correlations at C5' $\left(\delta_{\mathrm{C}} 83.01\right)$ of Fru. The spectrum also depicted three bond correlations between anomeric proton $\delta_{\mathrm{H}} 4.80$ of acetyldigitoxose moiety and $\delta_{\mathrm{C}}$ $104.49\left(\mathrm{C} 2\right.$ '-Fru) which showed the linkage to Fru. The two bond correlations can be seen between signal at $\delta_{\mathrm{H}} 3.90$ $\left(\mathrm{C} 5\right.$-glc-I) and $\delta_{\mathrm{C}} 62.69\left(\mathrm{C} 6\right.$-glc-I), $\delta_{\mathrm{H}} 3.47$ (C3-glc-I) and $\delta_{\mathrm{C}} 72.09\left(\mathrm{C} 2\right.$-glc-I) and $\delta_{\mathrm{C}} 70.30\left(\mathrm{C} 4\right.$-glc-I), $\delta_{\mathrm{H}} 3.14(\mathrm{C} 4-$ glc-I) and $\delta_{\mathrm{C}} 73.33\left(\mathrm{C} 3\right.$-glc-I), $\delta_{\mathrm{H}} 3.68\left(\mathrm{C}^{\prime}\right.$ '-Fru) and $\delta_{\mathrm{C}} 74.74\left(\mathrm{C}^{\prime}\right.$ '-Fru) and $\delta_{\mathrm{C}} 83.01$ (C5'-Fru). The three bond correlations were depicted between signal at $\delta_{\mathrm{H}} 3.68\left(\mathrm{C} 3^{\prime}-\mathrm{Fru}\right)$ and $\delta_{\mathrm{C}} 83.01(\mathrm{C} 5-\mathrm{Fru})$ and $\delta_{\mathrm{C}} 74.74\left(\mathrm{C} 4{ }^{\prime}-\mathrm{Fru}\right), \delta_{\mathrm{H}}$ $3.49\left(\mathrm{C} 1{ }^{\prime}-\mathrm{Fru}\right)$ and $\delta_{\mathrm{C}} 73.33\left(\mathrm{C} 3^{\prime}-\mathrm{Fru}\right), \delta_{\mathrm{H}} 5.18(\mathrm{C} 1-\mathrm{Glc})$ and $\delta_{\mathrm{C}} 70.30(\mathrm{C} 4-\mathrm{Glu}), \delta_{\mathrm{H}} 3.58\left(\mathrm{C} 5^{\prime}-\mathrm{Fru}\right)$ and $\delta_{\mathrm{C}} 104.49$ (C2'-Fru). The structure of sugar moieties and the HMBC correlation are shown in Figure 2 and 3 respectively. The proton and carbon NMR data of compound (1) in DMSO were summarized in Table 2.

Table 2. ${ }^{1} \mathrm{H}$ NMR $(600 \mathrm{MHz})$ and ${ }^{13} \mathrm{C}$ NMR $(150 \mathrm{MHz})$ data of AC1 in DMSO

\begin{tabular}{|c|c|c|c|c|}
\hline Position & DEPT & ${ }^{13} \mathrm{C}(\delta)(\mathrm{ppm})$ & ${ }^{1} \mathbf{H} \delta(\mathbf{p p m}), \mathbf{m}$ & HMBC \\
\hline \multicolumn{5}{|l|}{ Glu } \\
\hline 1 & $\mathrm{CH}$ & 92.21 & $5.19, \mathrm{~m}$ & $\mathrm{C} 2{ }^{\prime}, \mathrm{C} 4, \mathrm{C} 5$ \\
\hline 2 & $\mathrm{CH}$ & 72.09 & $3.20, \mathrm{~m}$ & \\
\hline 3 & $\mathrm{CH}$ & 73.27 & $3.47, \mathrm{~m}$ & $\mathrm{C} 2, \mathrm{C} 4$ \\
\hline 4 & $\mathrm{CH}$ & 70.30 & $3.14, \mathrm{~m}$ & $\mathrm{C} 4^{\prime}, \mathrm{C} 3$ \\
\hline 5 & $\mathrm{CH}$ & 77.47 & $3.90, \mathrm{t}$ & C6 \\
\hline 6 & $\mathrm{CH}_{2}$ & 62.59 & $3.55, \mathrm{~m}$ & \\
\hline \multicolumn{5}{|l|}{ Fru } \\
\hline 1 ' & $\mathrm{CH}_{2}$ & 60.95 & $3.49, \mathrm{~m}$ & C3' \\
\hline 2 ' & $\mathrm{C}$ & 104.49 & - & \\
\hline 3 ' & $\mathrm{CH}$ & 73.33 & $3.68, \mathrm{~m}$ & $\mathrm{C} 4^{\prime}, \mathrm{C} 5{ }^{\prime}$ \\
\hline 4 ' & $\mathrm{CH}$ & 74.74 & $3.78, \mathrm{~m}$ & $\mathrm{C} 2$ ' \\
\hline 5 & $\mathrm{CH}$ & 83.01 & $3.58, \mathrm{~m}$ & $\mathrm{C} 2$ \\
\hline 6 & $\mathrm{CH} 2$ & 62.51 & $3.43, \mathrm{~m}$ & \\
\hline \multicolumn{5}{|l|}{ GlcNAc } \\
\hline 1 & $\mathrm{CH}$ & & $4.41, \mathrm{~m}$ & $\mathrm{C} 3$ \\
\hline Acetyl digitoxose & $\mathrm{CH}$ & & $4.80, \mathrm{~m}$ & $\mathrm{C} 2$ ' \\
\hline
\end{tabular}




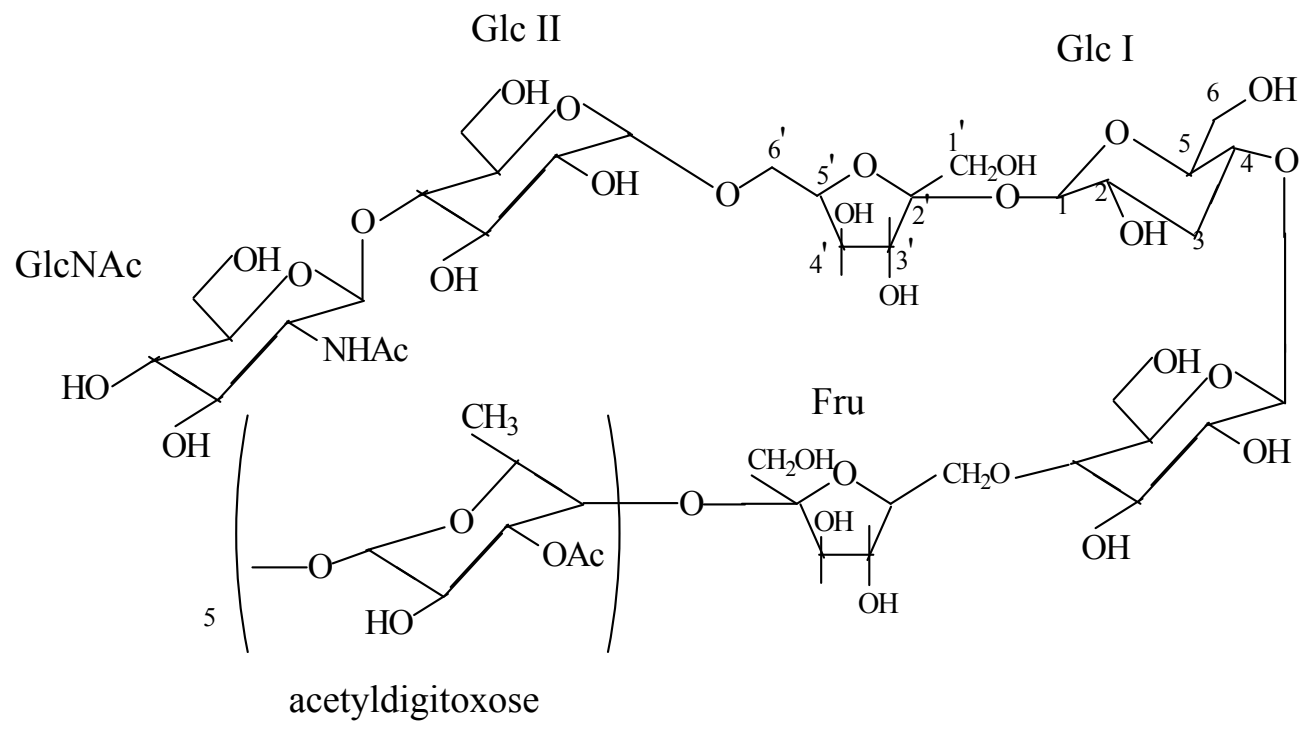

Figure 2. The structure of compound (1) from E. spiralis stem bark

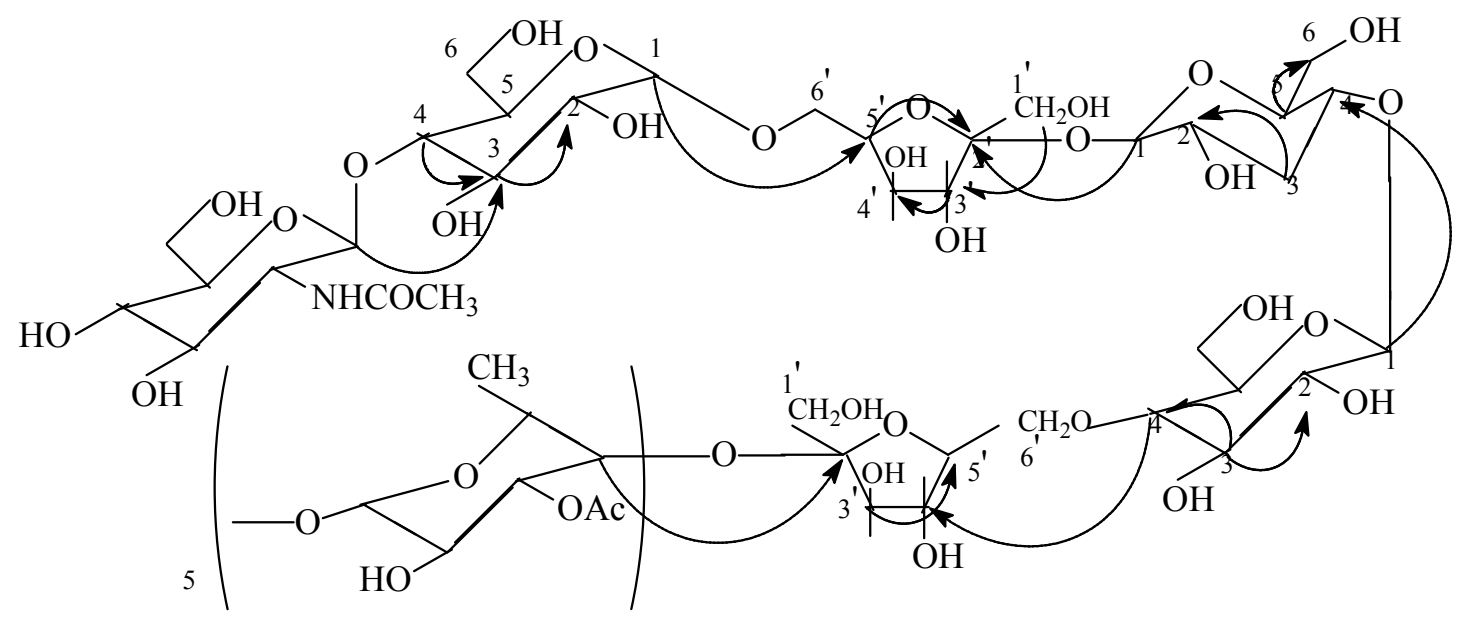

Figure 3. The key HMBC correlation of compound (1) from E. spiralis stem bark

After gone through an extensive spectroscopic analysis and comparison with literature, compound (1) was identified as penta-2-acetoxy- $\beta$-D-digitoxopyranosyl-( $1 \rightarrow 2)$-fructofuranosyl-(6 $\rightarrow 4)-\beta$-D-glucopyranosyl-( $1 \rightarrow 4)$-glucopyranosyl-( $(1 \rightarrow 2)-\beta$-Dfructofuranosyl-( $6 \rightarrow 1)-\beta-D$-glucopyranosyl-( $4 \rightarrow 1)$-acetylglucosamine.

Compound (2) was isolated as white crystalline solid after subjecting to vacuum liquid chromatography with an elution system of $\mathrm{CHCl}_{3}-\mathrm{MeOH}(7: 3 \mathrm{v} / \mathrm{v})$, whereby fraction obtained was found to exhibit moderate antidermatophytic activity. The UV absorption analysis has displayed two absorption peaks at 256 and $280 \mathrm{~nm}$ which indicated chromophore of C-O group. The ESIMS displayed $[\mathrm{M}+\mathrm{H}]^{+}$ion peak at $\mathrm{m} / z \mathbf{2} 22.0135$, supported a molecular formula of $\mathrm{C}_{35} \mathrm{H}_{59} \mathrm{O}_{28}$. The fragment ion peaks were observed on the ESIMS at $\mathrm{m} / z 600.5184[\mathrm{M}+\mathrm{H}-325]^{+}$ corresponding to the consecutive loss of two hexosyls. The $\mathrm{m} / \mathrm{z} 325.1126[\mathrm{M}+\mathrm{H}-325-278]^{+}$referred to the loss of 
one pentosyl and again one hexosyl. Further fragmentation ion peak is observed at $m / z 163.0607$ [M+H-325- 278$162]^{+}$, which showed the loss of another one hexosyl. The mass fragmentation is illustrated in Figure 4.

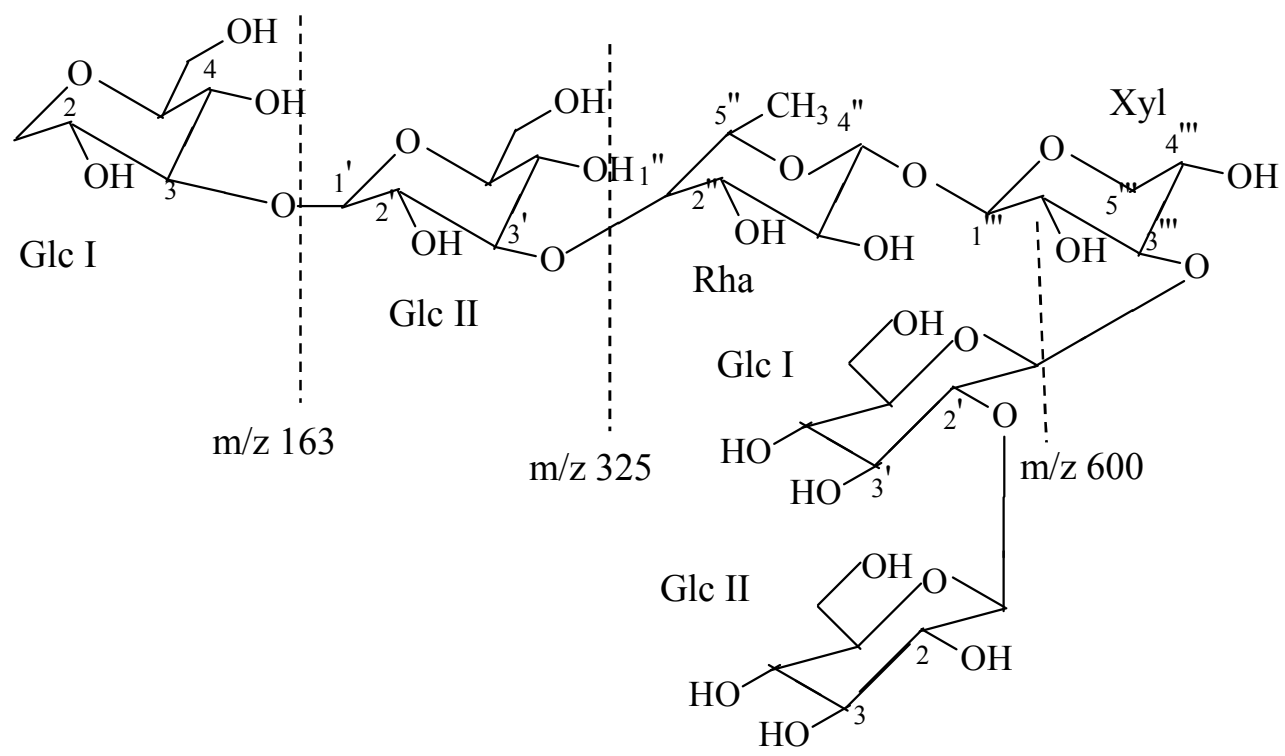

Figure 4. The mass fragmentations of compound (2) from E. spiralis stem bark

The sequences of the sugar chain were confirmed by HMBC experiments. The cross-peak observed in the HMBC spectrum between anomeric proton at signal $\delta_{\mathrm{H}} 4.4$ (Glc-1) and $\delta_{\mathrm{C}} 83.02\left(\mathrm{C} 2\right.$ '), $\delta_{\mathrm{H}} 5.05$ (Rha-1) and $\delta_{\mathrm{C}} 73.28\left(\mathrm{C} 3^{\prime}\right)$, $\delta_{\mathrm{H}} 4.78(\mathrm{Xyl})$ and $\delta_{\mathrm{C}} 73.33\left(\mathrm{C} 4{ }^{\prime \prime}\right), \delta_{\mathrm{H}} 5.20(\mathrm{Glc}-\mathrm{II})$ and $\delta_{\mathrm{C}} 73.28(\mathrm{C} 3)$, showed the location of sugar moieties.

Other correlations with two bond correlations can be observed between proton signal $\delta_{\mathrm{H}} 3.58\left(\mathrm{C} 2\right.$-glc I) and $\delta_{\mathrm{C}}$ $73.28(\mathrm{C} 3)$, and $\delta_{\mathrm{H}} 3.58\left(\mathrm{C} 2^{\prime}\right.$-Glc II) with $\delta_{\mathrm{C}} 73.28$ (C3'-Glc II). Three bond correlations can be seen between proton signal $\delta_{\mathrm{H}} 3.43\left(\mathrm{C} 5{ }^{\prime}\right.$-Rha) and $\delta_{\mathrm{C}} 70.30\left(\mathrm{C} 2\right.$ '), $3.55\left(\mathrm{C} 5{ }^{\prime \prime}\right.$ '-xyl) and $\delta_{\mathrm{C}} 74.75\left(\mathrm{C} 4\right.$ '"') and between $\delta_{\mathrm{H}} 5.20(\mathrm{C} 1$ '-Glc II) and $\delta_{\mathrm{C}} 77.48\left(\mathrm{C} 3{ }^{\prime \prime}\right.$ '-Xyl). The HMBC correlation is shown in Figure 5 and Table 3 showed the NMR data of compound (2).

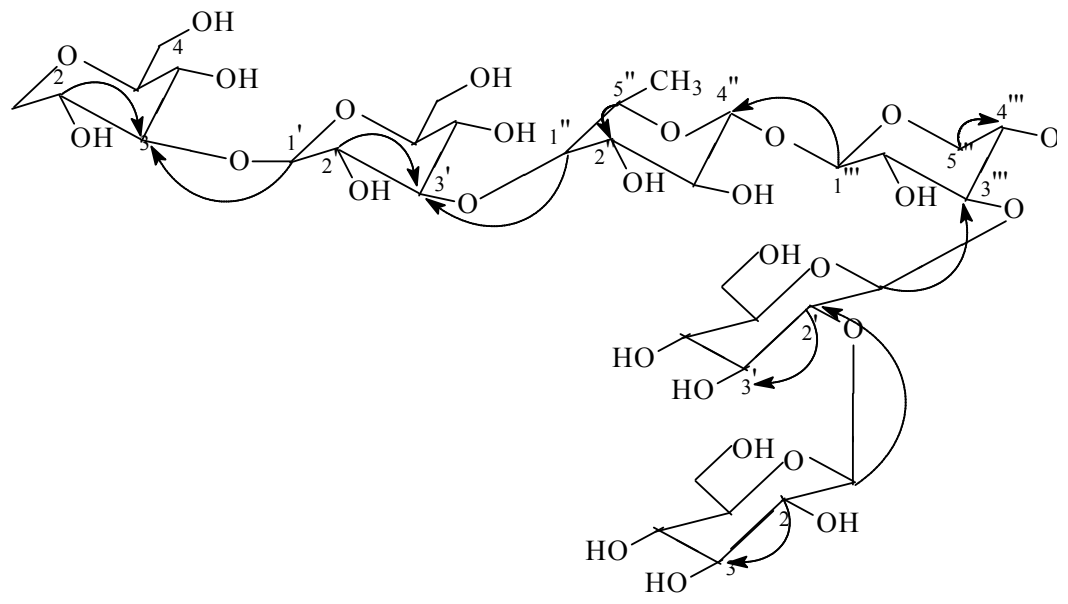

Figure 5. The key HMBC correlation of compound (2) from E. spiralis stem bark 
After went through an extensive spectroscopic analysis and comparison with literature, compound (2) was elucidated as $\beta, D$-glucopyranosyl $(1 \rightarrow 2)-\beta, D$-glucopyranosyl)-( $(1 \rightarrow 3)-\beta, D$-xylopyranosyl $(1 \rightarrow 4)$ - $\alpha$, L-rhamno pyranosyl)-( $(1 \rightarrow 3)-\beta, D$-glucopyranosyl $(1 \rightarrow 3)-\beta, D$-glucopyranoside as shown in Figure 6 .

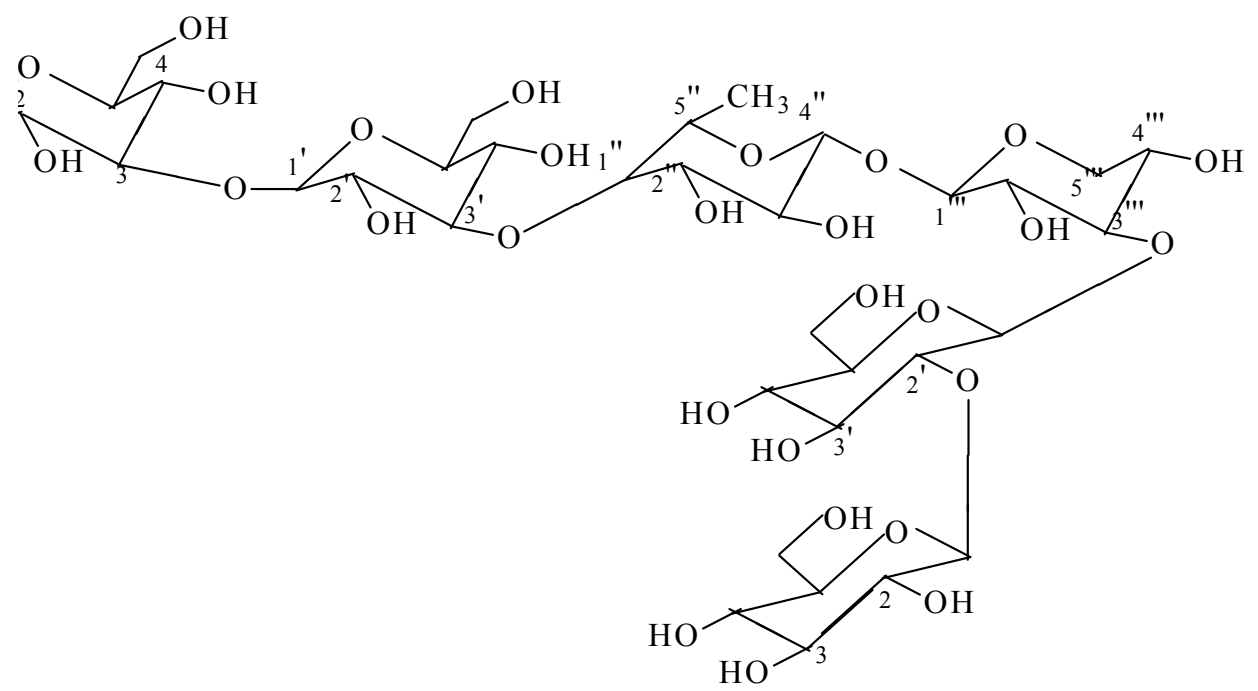

Figure 6. The structure of compound (2) from E. spiralis stem bark

Table 3. ${ }^{1} \mathrm{H}$ NMR (600 MHz) and ${ }^{13} \mathrm{C}$ NMR $(150 \mathrm{MHz})$ data of compound (2) in DMSO

\begin{tabular}{|c|c|c|c|c|}
\hline Position & DEPT & ${ }^{13} \mathrm{C}(\delta)(\mathrm{ppm})$ & ${ }^{1} \mathbf{H} \delta(\mathrm{ppm}), \mathrm{m}$ & HMBC \\
\hline \multicolumn{5}{|l|}{ Glc I } \\
\hline 1 & $\mathrm{CH}$ & 92.21 & $4.4, \mathrm{~m}$ & $\mathrm{C} 2$ \\
\hline 2 & $\mathrm{CH}$ & 83.02 & $3.58, \mathrm{~m}$ & $\mathrm{C} 3$ \\
\hline 3 & $\mathrm{CH}$ & 73.28 & $3.47, \mathrm{~m}$ & \\
\hline 4 & $\mathrm{CH}$ & 70.30 & $3.14, \mathrm{~m}$ & \\
\hline 5 & $\mathrm{CH}$ & 77.47 & $3.90, \mathrm{t}$ & \\
\hline 6 & $\mathrm{CH}_{2}$ & 62.59 & $3.55, \mathrm{~m}$ & \\
\hline \multicolumn{5}{|l|}{ Glc II } \\
\hline 1 ' & $\mathrm{CH}$ & 92.21 & $5.20, \mathrm{~m}$ & $\mathrm{C} 3, \mathrm{C} 3$,", \\
\hline 2 ' & $\mathrm{CH}$ & 83.02 & $3.58, \mathrm{~m}$ & $\mathrm{C} 3^{\prime}$ \\
\hline $3^{\prime}$ & $\mathrm{CH}$ & 73.28 & $3.47, \mathrm{~m}$ & \\
\hline $4^{\prime}$ & $\mathrm{CH}$ & 70.30 & $3.14, \mathrm{~m}$ & \\
\hline 5 & $\mathrm{CH}$ & 77.47 & $3.90, \mathrm{~m}$ & \\
\hline $6^{\prime}$ & $\mathrm{CH}_{2}$ & 62.51 & $3.43, \mathrm{~m}$ & \\
\hline
\end{tabular}


Aiza et al: TWO ISOLATED CRYSTALLINE SOLIDS FROM THE STEM OF Entada spiralis Ridl. (AKAR SINTOK)

Table 3 (cont'd). ${ }^{1} \mathrm{H}$ NMR (600 MHz) and ${ }^{13} \mathrm{C}$ NMR (150 MHz) data of compound (2) in DMSO

\begin{tabular}{|c|c|c|c|c|}
\hline Position & DEPT & ${ }^{13} \mathrm{C}(\delta)(\mathrm{ppm})$ & ${ }^{1} \mathbf{H} \delta(\mathrm{ppm}), \mathrm{m}$ & НМВС \\
\hline \multicolumn{5}{|l|}{ Rha } \\
\hline 1, & $\mathrm{CH}$ & - & $5.05, \mathrm{~m}$ & $\mathrm{C} 3^{\prime}$ \\
\hline $2 "$ & $\mathrm{CH}$ & 70.30 & $3.14, \mathrm{~m}$ & \\
\hline $3 "$ & $\mathrm{CH}$ & 72.09 & $3.20, \mathrm{~m}$ & \\
\hline 4" & $\mathrm{CH}$ & 73.33 & $3.68, \mathrm{~m}$ & \\
\hline $5 "$ & $\mathrm{CH}$ & 62.51 & $3.43, \mathrm{~m}$ & $\mathrm{C} 2{ }^{\prime}$, \\
\hline $6 "$ & $\mathrm{CH}_{3}$ & - & $2.5, \mathrm{t}$ & \\
\hline \multicolumn{5}{|l|}{ Xyl } \\
\hline 1, & $\mathrm{CH}$ & 104.49 & $4.78, \mathrm{~m}$ & $\mathrm{C} 4$, \\
\hline 2, & $\mathrm{CH}$ & 74.75 & $3.78, \mathrm{~m}$ & \\
\hline 3, & $\mathrm{CH}$ & 77.48 & $3.90, \mathrm{~m}$ & \\
\hline $4 "$, & $\mathrm{CH}$ & 70.30 & $3.14, \mathrm{~m}$ & \\
\hline 5, & $\mathrm{CH}_{2}$ & 60.95 & $3.49, \mathrm{~m}$ & $\mathrm{C} 4$, \\
\hline
\end{tabular}

\section{Conclusion}

Two types of crystalline solids from E.spiralis stem bark have been successfully isolated and characterized and they were determined as penta-2-acetoxy- $\beta$-D-digitoxopyranosyl-( $1 \rightarrow 2)$-fructofuranosyl-(6 $\rightarrow 4)-\beta$-Dglucopyranosyl-( $(1 \rightarrow 4)$-glucopyranosyl-( $1 \rightarrow 2)$ - $\beta$-Dfructofuranosyl-( $6 \rightarrow 1)$ - $\beta$-D-glucopyranosyl-( $4 \rightarrow 1) \quad$ acetylglu cosamine (1) and $\quad \beta$,D-glucopyranosyl $(1 \rightarrow 2)-\beta$,D-glucopyranosyl)-( $1 \rightarrow 3)-\beta$,D-xylopyranosyl $(1 \rightarrow 4)-\alpha, \mathrm{L}$ rhamnopyranosyl)-( $1 \rightarrow 3)-\beta, \mathrm{D}$-glucopyranosyl $(1 \rightarrow 3)-\beta, \mathrm{D}$-glucopyranoside $(\mathbf{2})$. Both compounds have been isolated from methanol extract which is antidermatophytic active constituents.

\section{References}

1. Mbosso, E. J. T., Ngouela, S., Nguedia, J. C. A., Beng, V. P., Rohmer, M. and Tsamo, E. (2010). In vitro antimicrobial activity of extracts and compounds of some selected medicinal plants from Cameroon. Journal of Ethnopharmacology, 128 (2): 476 - 481.

2. Prasad, S. C., Shukla, R., Kumar, A. and Dubey, N. K. (2010) In vitro and in vivo antifungal activity of essential oils of Cymbopogon martini and Chenopodium ambrosioides and their synergism against dermatophytes. Mycoses, 53 (2): 123 - 129.

3. Silva Silva, G. M., Teles, H. L., Zanardi, L. M., Marx Young, M. C., Eberlin, M. N., Hadad, R., Pfenning, L. H., Costa- Neto, C. M., Castro-Gamboa, I., Da Silva Bolzani, V. and Araujo, A. R. (2006). Cadinane sesquiterpenoids of Phomopsis cassiae, an endophytic fungus associated with Cassia spectabilis(Leguminosae). Phytochemistry, 67 (14): $1964-1969$.

4. Doughari, J. H. (2006). Antimicrobial activity of Tamarindus indica Linn. Tropical Journal of Pharmaceutical Research 5 (2): 597 - 603.

5. Duraipandiyan, V. and Ignacimuthu, S. (2007). Antibacterial and antifungal activity of Cassia fistula L.: An ethnomedicinal plant. Journal of Ethnopharmacology 112 (3): 590 - 594.

6. Khattak, K. F. and Simpson, T. J. (2010). Effect of gamma irradiation on the antimicrobial and free radical scavenging activities of Glycyrrhiza glabra root. Radiation Physics and Chemistry, 79: 507 -512.

7. Okada, Y., Shibata, S., Ikekawa, T., Javellana, Ana M. J. and Kamo, O. (1987). Entada Saponin III, A saponin Isolated from the bark of Entada phaseloides. Phytochemistry, 26 (10): 2789 - 2796.

8. Okada, Y., Shibata, S. and Javellana, A. M. J. (1988). Entada saponin (ES) II and IV from the bark of Entada phaseloides. Chemical and Pharmaceutical Bulletin, 36: 1264 - 1269. 
9. Tapondjou, A. L., Miyamoto, T., Mirjolet, J. F., Guilbaud, N. and Lacaille-Dubois, M. A. (2005). Pursaethosides A-E, Triterpene saponins from Entada pursaetha. Journal of Natural Products, 68 (8): 1185 1190.

10. Ikegami, F., Ohmiya, S., Ruangrungsi, N., Sakai, S. I. and Murakoshi, I. (1987). A second new sulphurcontaining amide from Entada phaseoloides seeds. Phytochemistry, 26 (5): 1525 - 1526.

11. Barua, A. K., Chakrabarty, M. and Datta, P. K.. (1988). Phaseoloidin, a homogentistic acid glucoside from Entada phaseoloides. Phytochemistry, 27: 3259 - 3261.

12. Dai, J., Kardono, L. B. S. and Tsauri, S. (1991). Phenylacetic acid derivatives and a thiomide glycosides from Entada phaseoloides. Phytochemistry, 30: 3749 - 3752.

13. Nzowa, L. K., Barboni, L., Teponno, R. B., Ricciutelli, M., Lupidi, G., Quassinti, L., Bramucci, M. and Tapondjou, L. A. (2010). Rheediinosides A and B, two antiproliferative and antioxidant triterpene saponins from Entada rheedii. Phytochemistry 71 (2), $254-261$.

14. Aiza, H., Siti Zaiton, M. S. and Norazian, M. H. (2015). Bioassay guided isolation of an antidermatophytic active constituent from the stem bark of Entada spiralis Ridl. Malaysian Journal of Analytical Sciences 19 (4): $752-759$.

15. Tibiri, A., Sawadogo, R. W., Ouedraogo, N., Banzouzi, J.-T., Guissou, I. P. and Nacoulma, G. O. (2010). Evaluation of Antioxidant Activity, Total Phenolic and Flavonoid Contents of Entada africana Guill.et Perr. (Mimosaceae) Organ Ectracts, Research Journal of Medical Sciences 4(2): 81 - 87.

16. Teke, G. N., Lunga, P. K., Wabo, H. K., Kuiate, J.-R., Vilarem, G., Giacinti, G., Kikuchi, H. and Oshima, Y. (2011). Antimicrobial and antioxidant properties of methanol extract, fractions and compounds from the stem bark of Entada abyssinica Stend ex A. Satabie. BMC Complementary and Alternative Medicine, 11(1): 57 - 65.

17. Iwamoto, Y., Sugimoto, S., Harinantenaina, L., Matsunami, K. and Otsuka, H. (2012). Entadosides A - D, triterpene saponins and a glucoside of the sulphur-containing amide from the kernel nuts of Entada phaseoloides( L .) Merrill, Journal Natural Medicine, 321 - 328.

18. Aiza, H., Siti Zaiton, M. S., Norazian, M. H. and Neni Kartini, C. M. R. (2014). Bioactive Terpenoids from the Stem Bark of Entada spiralis Ridl. (sintok). Proceeding of the International Conference on Science Technology and Social Science (ICSTSS) 2012. Chapter in Book Springer Science+Business Media Singapore. 605 - 615.

19. Aiza, H., Siti Zaiton, M.S., Norazian, M.H. and Neni Kartini, C. M. R. (2014b). In-vitro antidermatophytic activity of Methanolic fractions from Entada spiralis Ridl. Stem bark and its bioautographic profile. Pertanika Journal Science \& Technology 22(1): 113 - 121.

20. Aiza, H, Siti Zaiton, M.S., Norazian, M. H. and Neni Kartini, C. M. R. (2011). In-vitro antifungal activity of Entada spiralis Ridl. crude extract against dermatophytes of superficial skin disease. Revelation and Science, 1 (1), $57-61$.

21. Yokosuka, A., Kawakam, I. S., Haraguch, I. M. and Mimaki. Y. (2011). Seven new triterpene glycosides from the pericarps of Stryphnodendron fissuratum. Phytochemistry Letters 4 (3): $259-266$.

22. Warashina, T. and Noro, T. (2009). 8,14-Secopregnane glycoside from the aerial parts of Asclepias tuberosa Phytochemistry, 70 (10): $1294-1304$.

23. Okada, H., Fukushi, E., Yamamori, A., Kawazoe, N., Onodera, S., Kawabata, J. and Shiomi, N. (2010). Novel fructopyranose oligosaccharides isolated from fermented beverage of plant extract. Carbohydrate Research, 345 (3): $414-418$. 